\title{
'n Eksegese van 'n leksikografiese metode: Die WAT en die probleem van ensiklopedisiteit in die verklarende linguistiese woordeboek
}

\author{
Piet Swanepoel, Universiteit van Suid-Afrika, \\ Pretoria, Suid-Afrika
}

\begin{abstract}
An Exegesis of a Lexicographic Method: The Woordeboek van die Afrikaanse Taal (WAT) and the Problem of Encyclopedicity in Monolingual Linguistic Dictionaries. The WAT has often been criticised for its encyclopedic features. In this article a critical review is given of the metalexicographical points of view from which one of its editors, F.J. Snijman, motivates the so-called "encyclopedic" features of the WAT. Snijman shows convincingly that the problem of the encyclopedic nature of monolingual dictionaries cannot be reduced to a naive confusion between the linguistic meaning and knowledge of the referents of words, but that the "encyclopedic" lexicographical practices of monolingual dictionaries are well motivated, theoretically and pragmatically. It is argued, though, that Snijman does not motivate his own choice of metalexicographical points of view and does not discuss a number of critical issues in enough depth.
\end{abstract}

Keywords: LEXICOGRAPHIC METHOD, EXPLANATORY DICTIONARY, WOORDEBOEK VAN DIE AFRIKAANSE TAAL, ENCYCLOPEDIA, MEANING DESCRIPTION, ENCYCLOPEDICITY, REFERENTIAL MEANING, CONTEXTUALISM, TERMINOLOGY, ILLUSTRATIONS, EXAMPLES

Opsomming: Die WAT is al dikwels gekritiseer vir die ensiklopediese kenmerke daarvan. In hierdie artikel word daar 'n kritiese oorsig gegee van die metaleksikografiese uitgangspunte op grond waarvan een van die redakteurs van die WAT, F.J. Snijman, die sogenaamde "ensiklopediese" kenmerke in die WAT motiveer. Snijman toon op oortuigende wyse aan dat die probleem van die ensiklopediese in eentalig verklarende woordeboeke nie tot 'n naïewe verwarring van leksikale betekenis en saak herlei kan word nie, maar dat die "ensiklopediese" leksikografiese praktyke van eentalig verklarende woordeboeke goed gemotiveerd is, sowel teoreties as pragmaties. Daar word egter aangevoer dat Snijman nie self sy eie metaleksikografiese uitgangspunte motiveer nie en ' $n$ aantal belangrike kwessies onbespreek laat.

Resensieartikel oor Die leksikograaf as eksegeet. Opstelle en lesings deur F.J. Snijman (Stellenbosch: Buro van die WAT; AFRILEX-reeks 5A:1995) 
Sleutelwoorde: LEKSIKOGRAFIESE METODE, VERKLARENDE WOORDEBOEK, WOOR. DEBOEK VAN DIE AFRIKAANSE TAAL, ENSIKLOPEDIE, BETEKENISBESKRYWING, ENSTKLOPEDISITEIT, REFERENSIËLE BETEKENIS, KONTEKSTUALISME, TERMINOLOGIE, ILLUSTRASIES, VOORBEELDE

\section{Inleiding}

Leksikograwe is al dikwels daarvan beskuldig dat hulle woordeboeke oënskynlik deur geen duidelike leksikografiese beginsels onderlê word nie, of dat waar sulke uitgangspunte wel bestaan, daar 'n ooglopende diskrepansie bestaan tussen die teorie en dit wat in die praktyk in hulle woordeboeke neerslag vind.

Hierdie situasie het al aansienlik verander met die opkoms van die leksikografie as vakgebied. Vandag is dit algemene praktyk dat leksikograwe hulle leksikografiese uitgangspunte publiseer, of dat sulke teorieë (en die leksikografiepraktyke waartoe dit aanleiding gee) deel uitmaak van wetenskaplike ondersoek en kritiek.

Met die jongste publikasie van die Buro van die Woordeboek van die Afrikaanse Taal, nl. Die leksikograaf as eksegeet. Opstelle en lesings deur F.J. Snijman (Stellenbosch: Buro van die WAT; AFRILEX-reeks 5A:1995), het die redaksie van die WAT ook tot hierdie openbare, wetenskaplike debat toegetree. In hierdie huldigingsbundel vir dr. F.J. Snijman, wat vir 33 jaar lank aan die WAT verbonde was, die laaste 18 jaar as hoofredakteur, verskyn naamlik 'n hele aantal opstelle deur Snijman (sommige voorheen ongepubliseer), waarin sy leksikografiese werkwyse en teoretiese opvattings eksplisiet en implisiet aan bod kom.

Hierdie opstelle is van besondere belang weens die lig wat hulle werp op die sogenaamde "ensiklopediese" kenmerke van die eerste agt dele van die WAT. Ensiklopedisiteit is dié kenmerk waaroor die WAT sedert die verskyning van die eerste dele, telkemale onder skerp kritiek gekom het. Dit was tot dusver egter nog altyd beleid van die WAT om hom nie in die openbaar oor sodanige kritiek uit te spreek nie (vgl. Snijman 1995h: 201) — 'n stilswye wat nie alleen die wetenskaplike diskoers oor die ensiklopediese in die WAT tot nadeel gestrek het nie, maar ook die status van die WAT (veral onder taalkundiges) negatief beïnvloed het.

Die probleem van die ensiklopediese in die sogenaamde "linguistiese" verklarende woordeboeke is 'n onderwerp wat tans nog aktueel in die metaleksikografie staan (vgl. byvoorbeeld Wolf 1992), en daarom is hierdie opstelle van wesentlike belang vir die lig wat hulle werp op die teoretiese en praktiese aspekte van hierdie kategorie woordeboeke.

In hierdie artikel word daar gepoog om aan die hand van Snijman se opstelle 'n uiteensetting te gee van die metaleksikografiese uitgangspunte wat die ensiklopedisiteit onderlê en van die leksikografiese werkwyse waartoe dit aanleiding gee. In die tweede plek word daar gepoog om vanuit in aantal 
resente linguistiese en leksikografiese uitgangspunte 'n omvattender perspektief op die verskynsel van ensiklopedisiteit te bied.

\section{Die probleem van die term ensiklopedies}

Soos Wolf (1992: 1-2) tereg opmerk, is een van die kernprobleme in die gesprek oor die ensiklopediese in eentalige, verklarende linguistiese woordeboeke (voortaan verkort tot verklarende woordeboek(e)) dat daar nie altyd duidelikheid oor die kernterme in die gesprek bestaan nie. Daar is dus 'n aantal kardinale aspekte wat eers om duidelikheid vra.

In die meeste gevalle word die adjektief ensiklopedies in toepassing op verklarende woordeboeke gebruik om te verwys na die feit dat laasgenoemde kenmerke van die ensiklopedie as woordeboektipe inkorporeer. Hierdie gebruik gaan terug op die byna kategoriale onderskeid wat daar tussen verskillende woordeboektipes, in die besonder tussen die ensiklopedie en die verklarende woordeboek, in woordeboektipologieë gemaak word (vgl. byvoorbeeld Zgusta 1971: 198-221).

Zgusta (1971) waarsku egter duidelik dat hierdie tipologie waarin 'n rigiede onderskeid tussen die ensiklopedie en die verklarende woordeboek getref word, ' $n$ idealisering van die woordeboekwerklikheid is. Dit geld in die besonder hierdie twee tipes, omdat bestaande ensiklopedieë kenmerke van die verklarende woordeboek inkorporeer, en omgekeerd, omdat verklarende woordeboeke kenmerke van die ensiklopedie vertoon. Dit onderstreep die feit dat daar moeilik, en dan in abstracto, 'n rigiede onderskeid tussen die ensiklopedie en die verklarende woordeboek as woordeboektipes getref kan word.

In die meeste woordeboektipologieë word daar ook nie 'n duidelike kategorie van ensiklopediese verklarende woordeboeke onderskei nie, alhoewel daar al sedert Samuel Johnson se Dictionary of the English Language na verskeie verklarende woordeboeke as ensiklopediese woordeboeke verwys is (vgl. Wolf 1992: 1-2). Miskien is dit daarom veel nuttiger om die (geïdealiseerde) suiwer ensiklopedie en die suiwer verklarende woordeboek op die eindpunte van 'n klien te plaas, en om individuele woordeboeke as nader of verder van enige van hierdie eindpunte te klassifiseer in terme daarvan of hulle in meerdere of mindere mate van die makro- en mikrostrukturele kenmerke van die ensiklopedie of die verklarende woordeboek vertoon.

Daar bestaan die neiging in die kritiek op die ensiklopediese in verklarende woordeboeke om die verskil tussen die twee tipes tot 'n enkele mikrostrukturele kenmerk te reduseer, $\mathrm{nl}$. die verskil in die objek van beskrywing van die artikels. In die ensiklopedie word dié gesien as die komplekse geheel van (wetenskaplike) kennis oor die saak, onderwerp of tema waarna die lemma verwys, in die verklarende woordeboek as die "linguistiese" betekenis van die lemma. Alhoewel dit 'n belangrike verskil is, kom dit neer op oorvereenvoudiging van die hele problematiek omdat die ooreenkomste en verskille oor 
die hele spektrum van die voor- en agterwerk, en die makro- en mikrostruktuur van elk kan voorkom.

Duidelikheidshalwe is dit daarom nuttig om te let op Wolf (1992) se ontleding van die makro- en mikrostrukturele kenmerke van die letter $G$ in die Encyclopaedia Britannica. Hieruit blyk die volgende:

\section{Makrostrukturele kenmerke (1814 lemmas)}

(a) eiename (1319 lemmas; $72,71 \%$ )

(b) selfstandige naamwoorde ( 455 lemmas; $25,08 \%$ )

(c) ander (40 meerwoordige leksikale items wat vir opname onder $G$ kwalifiseer omdat hulle bepalers van die eiename onder (a) afgelei is; $2,21 \%$ ).

Al die lemmas is naamwoorde, waarvan die eiename die grootste groep uitmaak. Alle soorte naamwoorde word egter nie opgeneem nie. Voornaamwoorde en ander naamwoorde wat hulle nie tot 'n ensiklopediese hantering leen nie, kom selde voor. Ander woordsoorte as die naamwoord (byvoorbeeld adjektiewe, setsels en werkwoorde) kom selde aan bod in die ensiklopedie, hoofsaaklik omdat daar nog min wetenskaplike ondersoek is na die verskynsels waarna hulle verwys.

Die meeste ensiklopedieë bevat as deel van die agterwerk ook 'n indeks van behandelde leksikale items omdat nie alle behandelde leksikale items die status van ' $n$ lemma in die ensiklopedie kry nie. Ensiklopediese artikels is afgestem op die behandeling van 'n tema / onderwerp; gevolglik word nie elke leksikale item wat met 'n onderwerp verband hou as lemma opgeneem nie, maar wel as inskrywings binne artikels.

\section{Mikrostrukturele kenmerke}

Wolf (1992: 18 e.v.) verdeel die beskrywende deel van ensiklopediese artikels in drie tipes, nl. kruisverwysings, definisies en ensiklopediese artikels. Kruisverwysings lei die gebruiker na ander artikels waar 'n onderwerp vollediger behandel word. Die definisies bied kort beskrywinge van die betrokke saak aan en stem in hierdie opsig, ook wat die aantal onderskeidende betekeniskenmerke betref, dikwels ooreen met leksikografiese definisies. Hierdie soort definisie word gevolg deur 'n kruisverwysing na 'n ensiklopediese artikel waarin die saak / tema in meer volledigheid bespreek word.

Bogenoemde twee soorte beskrywings vorm verreweg die minderheid in die Encyclopaedia Britannica. Die grootste gros $(92,89 \%)$ word opgemaak deur ensiklopediese beskrywings waarvan die kortste een of twee paragrawe beslaan en die langste oor etlike kolomme en bladsye loop. Die tipiese behandelingswyse is die verskaffing van veel meer inligting oor ' $n$ bepaalde saak as net dit waarvoor die saak algemeen bekend staan. Die mikpunt is om spesifieke en bykomende inligting oor die saak en oor die hele kennisveld (waar- 
binne die betrokke saak gesitueer is) te verskaf. Hierdie uitvoerige behandeling van 'n onderwerp bring noodwendig mee dat ensiklopediese artikels oor die algemeen lank is.

Ander relevante kenmerke van ensiklopedieë word verder hier onder bespreek. Wat hier van belang is, is die feit dat hierdie empiriese gegewe oor die Encyclopaedia Britannica as 'n belangrike maatstaf dien vir die beoordeling van die ensiklopediese kenmerke van verklarende woordeboeke. Soos Wolf (1992) telkens tereg opmerk, moet daar by die beoordeling van elkeen van hierdie kenmerke ook altyd gevra word in hoe 'n mate (kwalitatief) verklarende woordeboeke hierdie kenmerke vertoon. As verklarende woordeboeke byvoorbeeld wel eiename opneem, dan is die opname van enkeles daarvan byvoorbeeld nog nie naastenby te vergelyk met die hoë opname daarvan in die ensiklopedie nie. Daar is dus weinig grond daarvoor om 'n verklarende woordeboek op grond van enkele opnames van eiename as 'n "ensiklopedie" te bestempel.

Insgelyks moet daar, wat die bewerking van lemmas betref, telkens bepaal word watter ooreenkomste en verskille daar tussen die twee woordeboektipes se werkwyse en doelstelling is en in hoe 'n mate die verklarende woordeboek in hierdie opsig met die ensiklopedie ooreenkom. Ensiklopediese artikels maak byvoorbeeld verreweg die grootste deel van die ensiklopedie uit, terwyl sommige verklarende woordeboeke slegs in die minderheid gevalle ensiklopediese artikels bevat. Kortom: die aanwesigheid van 'n ensiklopediese kenmerk in ' $n$ woordeboek maak nog nie daarvan 'n ensiklopedie nie.

Verklarende woordeboeke word om verskeie ander redes ook as "ensiklopedies" bestempel, byvoorbeeld op grond van die opname van tabelle en illustrasies in hulle voor- en agterwerk of in die hoofdeel van die woordeboek, die opname van terminologie, en die gebruik van voorbeeldsinne om ensiklopediese inligting in te voer. Soos Wolf $(1992: 7,268)$ tereg opmerk, is dit nie net kenmerke van die ensiklopedie en die meeste verklarende woordeboeke nie, maar ook van 'n verskeidenheid ander tekstipes. Die aanwesigheid van hierdie kenmerke in enige verklarende woordeboek kan dus nie sonder meer as 'n ensiklopediese kenmerk daarvan bestempel word nie. In sulke gevalle het dit meer sin om hulle as "neutrale" kenmerke van altwee tipes te beskou.

'n Tweede belangrike faktor waarop gelet moet word, is die feit dat wat as linguisties in ' $n$ verklarende woordeboek beskou word, direk bepaal word deur die besondere uitgangspunte of kernaannames van ' $n$ bepaalde linguistiese teorie. Gegee die veelvoud van linguistiese teorieë (in die besonder oor kernaspekte van die leksikale semantiek) moet dit duidelik gestel word hoe die grens tussen die linguistiese en die nielinguistiese en tussen die linguistiese en die ensiklopediese in sulke teorieë bepaal word. Ook in die kritiek op die ensiklopediese karakter van die verklarende woordeboek moet dit duidelik gestel word teen watter linguisties teoretiese aannames sulke kritiek gelewer word.

In hierdie verband is dit ook belangrik om ten opsigte van die betekenisbeskrywing van lemmas daarop te let dat nielinguisties en ensiklopedies (d.w.s. 
"kenmerkend van die ensiklopedie") mekaar nie wedersyds in alle kontekste van die debat impliseer nie. Die etiket "nielinguisties" word in die literatuur ook byvoorbeeld gebruik om te verwys na die feit dat verklarende woordeboeke in hulle definisies aspekte van die linguistiese gebruikskonteks inkorporeer - ' $n$ verskynsel wat bekend staan as kontekstualisme (vgl. Snijman 1995h: 208-209). Wat in hierdie konteks as linguisties of nielinguisties ten opsigte van die betekenis van woorde beskou word, is ook ' $n$ teoriegebonde kwessie en slaan nie noodwendig op die ensiklopediese karakter van 'n woordeboek nie.

In ander gevalle gaan dit wesentlik nie om prinsipieel-teoretiese kwessies nie, maar om bepaalde aannames oor wat die beste vorm van leksikografiese betekenisbeskrywing is. Die bondeling en splyting ("lumping" en "splitting") van gebruikstoepassinge in een of meerdere betekenisonderskeidings is byvoorbeeld een so ' $n$ kwessie. In ander gevalle word hierdie verskynsels wel met prinsipieel-teoretiese kwessies verbind. In Combrink (1979) se kritiek op die WAT word byvoorbeeld aangevoer dat splyting (in die gedaante van die oordifferensiëring van betekenisonderskeiding) en kontekstualisme (as inkorporering van betekeniskomponente uit die taalgebruikskonteks in die betekenis van ' $n$ woord) spruit uit die saakgerigtheid in die betekenisverklaring in verklarende woordeboeke.

By die beoordeling van 'n woordeboek is dit dus ook noodsaaklik om vas te stel vanuit watter linguisties teoretiese aannames oor leksikale betekenis die leksikograaf vertrek, hoe hierdie uitgangspunt sy leksikografiese metode onderlê, op watter metaleksikografiese vertrekpunte kritiek teen 'n verklarende woordeboek gebaseer is, en watter geldigheid alternatiewe metodes het wat vir die leksikograaf voorgestel word.

In die bespreking hier onder sal hierdie sake aan bod kom, veral omdat Snijman in sy behandeling van die ensiklopediese in die verklarende woordeboek, en die WAT in die besonder, telkemale elke kenmerk vanuit die prinsipieel-teoretiese en die metodiese perspektief behandel en beoordeel.

\section{3. "Ensiklopediese" kenmerke van die WAT}

In Snijman (1995f: 179 e.v.) word die ensiklopediese van die WAT herlei tot 'n aantal "uiterlike of metodiese" kenmerke van die ensiklopedie, nl.

\section{Makrostrukturele kenmerke}

(a) die opname van tegniese en wetenskaplike terme, en

(b) die opname van naamwoorde "met 'n geringe algemene toepaslikheid, soos eiename en plekname, name van gebeurtenisse, ontwikkelinge, strominge, verskynsels, stowwe, organismes, e.d., en name wat as etiket kan dien ter identifikasie van 'n kenniskompleks" (Snijman 1995f: 174). 


\section{(ii)}

\section{Mikrostrukturele kenmerke}

(a) die behandeling op een alfabetiese plek van 'n groep woorde,

(b) die aangee van te veel saakbesonderhede in die artikels, en

(c) artikels wat in die algemeen te lank is.

'n Saak waarop Snijman self in meer besonderhede ingaan, is die gebruik van illustrasiemateriaal in die verklarende woordeboek (vgl. Snijman 1995e).

(i)(a) en (i)(b) het te make met die seleksie en opname van spesifieke lemmas. (ii)(a) slaan op sowel die seleksie van lemmas as hulle rangskikking in aparte woordeboekartikels of nie. (ii)(b) slaan op die inkorporering (in die woordeboekartikel) van te veel saakkenmerke wat aan die referent van die woord behoort.

Die lengte van woordeboekartikels kan die resultaat wees van (ii)(a) en (ii)(b), maar verskeie faktore kan hiervoor verantwoordelik wees, sodat dit nodig sal wees om nader ondersoek in te stel na wat alles tot die lengte van die woordeboekartikels in die WAT bydra.

Snijman bespreek sommige van hierdie sake nie in diepte sodat daar 'n breër perspektief hierop gebied word nie. Aangesien soveel van die argumente oor die ensiklopediese in die WAT geraak word deur Snijman se opvattinge oor die verhouding tussen linguistiese betekenis en kennis van die referent van 'n woord, kom hierdie saak eerste aan bod.

\subsection{Ensiklopediese definisies}

Een van die algemeenste punte van kritiek teen die WAT is dat betekenisbeskrywing met saakbeskrywing verwar word, dat kennis van die saak (die referent van ' $n$ woord) en nie die betekenis van ' $n$ woord nie, as uitgangspunt van betekenisbeskrywing en verklaring dien.

Die probleem van die verwarring van saak en betekenis kom in verskeie van Snijman se opstelle in hierdie bundel aan die orde. Wat opvallend is, is dat Snijman en die kritici van die WAT, soos Eksteen en Combrink (vgl. Eksteen 1968 en Combrink 1979) van dieselfde teoretiese standpunte vertrek Snijman motiveer egter die leksikografiese definisies in die WAT met hierdie standpunte, terwyl die kritici dit weer inspan as basis vir hulle kritiek.

Altwee kampe aanvaar in beginsel

- dat die betekenis van 'n leksikale item die objek van beskrywing van die leksikografiese definisie moet wees, en dat die leksikograaf uit taalgebruiksgevalle die omvattende betekenis van 'n woord moet abstraheer.

Snijman (1995g: 190) stel dit byvoorbeeld eksplisiet dat die betekenisbeskrywing in die WAT nie op 'n naïewe identifikasie van woord en saak berus nie, 
maar dat dit gestuur word deur (i) algemeen aanvaarde linguisties-teoretiese uitgangspunte en (ii) legitieme pragmaties-leksikografiese oorwegings.

Schoonees, Snijman se voorganger as hoofredakteur van die WAT, wat instemmend deur Snijman aangehaal word, het sy standpunt in hierdie verband duidelik gestel (Snijman 1995f: 177):

Ons uitgangspunt is altyd die woord, soms met die nodige toeligting van die definisie, en nooit die omvattende begrip nie, wat meestal die uitgangspunt van die ensiklopedie vorm.

Aangesien die uitgangspunte van Combrink (1979) en Eksteen (1968) goed bekend is, word hier onder veral aandag gegee aan Snijman se beskouing van die saak en die wyse waarop hy linguisties-teoreties en metodies van die kritici verskil.

Snijman en sy voorganger stel hulle baie duidelik op die uitgangspunte van prestrukturele tradisionele taalkundiges soos De Groot en Reichling ten opsigte van leksikale betekenis. Eenvoudig gestel, is die kernaanname dat die betekenis van 'n leksikale item die geheel van sy werklike (maar ook potensiële) gebruikstoepassinge is. In elke gebruikskonteks kan enige (maar meestal nooit alle nie) van hierdie toepassinge in perspektief gestel of geaktiveer word.

Snijman (1995a: 123) som dit só op:

Die betekenis van 'n woord, soos dit hom op allerlei wyses manifesteer in taalgebruiksgevalle, is dus 'n kompleks wat dié gebruiksmoontlikhede as potensialiteite bevat.

Die potensialiteitsaspek word ook verbind met betekenisverandering: enige van die komponente van die omvattender betekenis van 'n woord kan as basis vir verdere betekenisverandering dien (Snijman 1995c: 141):

So gesien, is die betekenis dus 'n potensialiteit nie alleen van moontlikhede wat reeds tot verwerkliking gekom het nie, maar ook van moontlikhede wat miskien pas later tot ontwikkeling kan kom. Ten opsigte van dié moontlikhede is dit dus in 'n gegewe stadium in beginsel ' $n$ min of meer oop potensialiteit - wat die basis vorm van taalontwikkeling en -aanpasbaarheid op die vlak van woordbetekenis.

Die sentrale objek van leksikografiese beskrywing is dus die woordbetekenis as potensialiteit, as geheel van kennis wat met 'n woordvorm geassosieer word. Aangesien enige definisie ' $n$ potensialiteit ten opsigte van gebruik aangee, kan daar in enige gegewe gebruikskonteks minder onderskeidinge geaktueer word as wat in die leksikografiese beskrywing van die betekenis van 'n woord latent gegee word (Snijman 1995a: 125).

Snijman (1995f: 185) stel dit kategories dat die opgetekende materiaal (taalgebruiksgevalle) die basis van die hele woordeboek vorm: "Dit vorm die 
grondslag van woordopname, betekenisomskrywing en -geleding." Die uitdaging vir die leksikograaf is egter om uit hierdie taalgebruiksgevalle die betekenis van die woord as potensialiteit te abstraheer.

Ten opsigte van die verhouding tussen die referent van 'n woord / kennis van die referent en die betekenis van ' $n$ woord, word daar in hierdie benadering geen wesentlike onderskeid tussen hierdie twee getref nie. Die hoofmotivering hiervoor is die feit dat kennis van die referent van ' $n$ woord deel kan uitmaak van die kennis / betekenis wat met 'n woord geassosieer word (insluitende kennis van aspekte soos die struktuur, funksie, kleur, ens. van konkrete denotata). Verdere motivering is die feit dat die betekeniswaardes van woorde in taalgebruiksgevalle soms na een of meerdere van (die kennis van) hierdie saakkenmerke van referente teruggevoer kan word. Vanuit die geaktiveerde gebruikstoepassinge van 'n woord is dit dus nie moontlik om teoreties of prinsipieel tussen "linguistiese" betekeniskenmerke en "ensiklopediese" saakkenmerke te onderskei nie. In beginsel hou dit in dat enige aspek van hierdie kennis van die saak in taalgebruik geaktiveer kan word (vgl. Snijman 1995f: 183184). Die ensiklopediese aard van woordeboekdefinisies lê dus nie in die opname van sogenaamde "buitelinguistiese" kenmerke nie, maar meestal in te veel kenmerke (vgl. ook Wolf 1992: 289).

Gegee die potensialiteit van woordbetekenis (en die oopheid van hierdie potensialiteit), is die primêre bron oor die betekenis van 'n woord eerstens taalgebruiksvoorbeelde (vgl. Snijman 1995a: 125; 1995d: 145; 1995f: 185), wat aandui watter aspekte van hierdie potensialiteit op 'n gegewe stadium in ' $n$ taal (in alle moontlike gebruikskontekste) wel geaktueer word.

In Snijman se repliek op Eksteen se kritiek op die ensiklopediese in die WAT (vgl. Snijman 1995g: 191-192) wys hy op 'n paar belangrike sake met betrekking tot die gebruik van taalmateriaal vir betekenisabstraksie en -beskrywing. Die eerste punt is dat die betekenis van ' $n$ woord in baie gevalle taamlik juis uit die taalgebruiksvoorbeelde agterhaal kan word, maar dat daar ook niedefinitoriese sinne voorkom waar die leksikograaf hom juis op sy eie kennis van die betekenis van die woord en sy kennis van die referent daarvan moet beroep om die betekenis daarvan te kan agterhaal (vgl. ook Snijman 1995b: 133; Wolf 1992: 284-285).

Dieselfde punt bring Snijman (1995h: 209-210) tuis met die interpretasie van samestellings soos springbok ("bok wat spring") en springmielies ("mielies wat in warm olie gespring word"). Die feit dat springmielies nie geïnterpreteer word as "mielies wat spring" nie toon dat die taalgebruiker onvermydelik by die korrekte interpretasie van sulke samestellings sy sogenaamde "buitelinguistiese" kennis moet betrek.

In ander gevalle kan die kontekstuele gegewens in voorbeeldsinne allerlei nietersaaklike inligting verskaf wat nie wesentlik tot die leksikale betekenis van so 'n item in die meeste "linguistiese" woordeboeke gereken sou kon word nie. Wolf (1992: 284-285) maak in hierdie opsig die opmerking dat die gebruik van 'n omvattender korpus taalgebruiksvoorbeelde nie noodwendig die leksiko- 
graaf se probleem sal oplos nie omdat die gebruik daarvan geen waarborg is dat die leksikograaf met 'n ander definisie vorendag sou kon kom as juis een wat uit wans uit opgestel is deur na die referent se kenmerke te gaan kyk nie.

Snijman wys ook daarop dat die leksikograaf hom / haar nie net op die geaktueerde betekeniswaardes van woorde in taalgebruiksgevalle kan rig nie, maar ook moet let op dié wat ter sake is in die omvattender semantiese veld waarbinne 'n enkele woord gesitueer is. Snijman (1995f: 182) stel dit kategories dat die invoer van wat as "ensiklopediese" kenmerke in definisies beskou word, dikwels dus in die funksie staan "van begrip en van gebruik van die woord as deel van die taal". Die werkwyse wat hiervoor ingespan word, beskryf hy soos volg:

Prinsipieel kom dit min of meer neer op identifisering (binne 'n groep samehangende woorde) deur kontrastering, en differensiëring met die oog op funksionering, saamgevat in 'n geheel wat formeel aangebied word as ' $n$ verklaring.

Daarin staan "die gebruik van die woord: op sigself, in gewone en idiomatiese gebruik, in samestellings en afleidings, en, as die woord veelsinnig is, in funksie van die ander betekenisse wat daarmee saamhang", sentraal (Snijman 1995f: 182). (Vgl. Snijman (1995c) vir 'n illustrasie van hierdie werkwyse in die ontleding van die betekeniswaardes van kant.) Snijman stel dan ook in verskeie opstelle die standpunt dat daar in die definiëring van 'n woord en by die seleksie van kenmerke daarvoor, rekening gehou moet word met die vele relasies waarin 'n woord staan en waardeur dit geïndividueer word (vgl. veral die uitgebreide bespreking in Snijman (1995d)). Snijman laat hom dus ook baie duidelik lei deur die strukturalistiese uitgangspunt van individuering in en deur die komplekse semantiese veld waarin ' $n$ woord gesitueer is. Dit is juis hierdie poging om die woord ook taalintern in die semantiese veld daarvan te situeer dat veel meer kenmerke in die leksikografiese definisies in die WAT ingevoer word.

Snijman (1995f: 183-184) illustreer die werking van hierdie uitgangspunt in sy repliek op die voorstel van Van Heerden (1977) dat die definisie van die woord koei in WAT aangevul moet word met die kenmerk "swaar dier met groot pote" omdat dit geaktueer word in die sin "O wêreld! 'n Koei in die tuin!". Snijman wys daarop dat hierdie kennis teruggaan op ons saakkennis van koeie, en dat dit daarom potensieel as betekeniskenmerk wat op hierdie saakkennis berus, vir opname kwalifiseer. Wat dit egter as bruikbare kenmerk diskwalifiseer, is die feit dat dit nie ook as kenmerk relevant blyk te wees in die relasie van koei in die semantiese veld met bul, vers, ens. nie.

Insgelyks is Eksteen se voorstel dat die lemma klok eenvoudig en kort gedefinieer word as "ding wat lui" vir Snijman onaanvaarbaar, alhoewel dit heel waarskynlik as definisie 'n beskrywing gee van die algemene kennis / betekenis wat met hierdie woord geassosieer word. Ook hier was die oorwe- 
ging by die leksikograwe van die WAT die feit dat die klok ' $n$ bekende kultuurvoorwerp in Suid-Afrika is (wat die illustrasie en benoeming van onderdele regverdig), maar daarbenewens moes meer inligting geïnkorporeer word om klok se betekenis in die gebruiksgevalle en in die uitdrukkings, samestellings en afleidings en verwante woorde te onderskei.

Srijman (1995h: 209-210) se repliek op Combrink (1979) se kritiek dat nietersaaklike, kontekstuele gegewens as deel van die definisie van 'n woord betrek word, moet ook teen die agtergrond van bostaande uitgangspunte gesien word. Snijman gaan naamlik van die standpunt uit dat dit in feite nie saak maak of die betrokke kenmerke teruggaan op saakkenmerke of kenmerke wat as linguisties bestempel word nie, maar dan wel of hulle vir die betekenis en betekenisrelasies van die betrokke leksikale item ter sake is.

Die punt is dat as daar nie prinsipieel tussen linguistiese en saakkenmerke onderskei kan word nie, dan is die verskil in die verklarende woordeboek en die ensiklopedie 'n kwessie van die hoeveelheid kenmerke wat ter sake is om die betekenis van woorde te beskryf, nie die aard van die kenmerke self nie (vgl. ook Wolf 1992: 290).

Snijman (1995h: 205) verwerp ook Combrink (1979) se kritiek dat die verdeling in betekenisonderskeidings in die WAT oënskynlik gerig word deur saaktipes waarna die woorde verwys. Snijman se uitgangspunt is egter dat die onderskeiding van saaktipes dikwels saamval met die verskillende toepassingsvelde van ' $n$ woord. By die leksikograwe van die WAT gaan dit dus nie primêr om saaktipes nie, maar om betekenisverskille in verskillende toepassingsvelde (byvoorbeeld in sekere wetenskappe), soos duidelik uit gebruiksvoorbeelde agterhaal sou kon word.

Die bondeling en splyting van betekeniswaardes bly egter 'n komplekse probleem waaraan Snijman in sy uiteensetting nie voldoende aandag gee nie (vgl. byvoorbeeld die bespreking in Geeraerts (1993) en Taylor (1992) van die teoretiese en praktiese probleme).

Snijman gee egter toe dat daar in die seleksie van betekeniskomponente vir definisies ook nog meer as die bostaande (betekeniswaardes in gebruikskontekste, die semantiese veld van 'n leksikale item) op die spel is. Hier bo is alreeds melding gemaak van die kultuurhistoriese belang van die referent van ' $n$ woord (byvoorbeeld die klok), wat op sigself ' $n$ aanduiding is dat die besondere inligtingsbehoeftes van die teikengebruikers ' $n$ bepalende rol speel in die opname van spesifieke betekeniskomponente in die leksikografiese definisie. Ander oorwegings op grond waarvan en waarteen die opname van bepaalde betekeniskomponente of beskrywende komponente in die WAT se definisie gemotiveer kan word, is die volgende:

- die invoer van inligting oor die etimologie van 'n woord, die naamgewingsgronde en "die perspektief van die woord op die saak" (Snijman 1995f: 183); en

- die invoer van kenmerke om definisies se begryplikheid en hulle presiesheid te verhoog (Snijman 1995f: 182). 
Die probleem om komplekse konsepte in enkele beskrywende woorde vas te vat, is welbekend aan leksikograwe - meer kenmerke of langer beskrywings om vir die gebruiker 'n duidelike begrip van 'n lemma se betekenis te gee, dwing dus langer beskrywings af. Presisering, d.i. onderskeiding van die algemene na die meer besondere betekenisonderskeidings, vereis meestal dat meer onderskeidende kenmerke betrek moet word, soos verwysings na die inherente en relasionele kenmerke van 'n saak.

Die lengte van definisies word ook beïnvloed deur die opname van definitories kwalifiserende uitdrukkings, wat nie op grond van saakbesonderhede gemotiveer word nie, maar om die toepassingsbereik van die definisies beter te kwalifiseer. Byvoorbeeld: "gewoonlik" en "dikwels" word as beperking gebruik om te onderskei tussen wat tipies tot 'n kategorie gereken word en wat net per geleentheid tot 'n kategorie gereken kan word. Die noodsaak hiervoor word geillustreer deur Combrink (1979) se voorstel om koekblik eenvoudig te definieer as "Blik ${ }^{1}$ (bet. 2), trommel waarin koek gebêre, bewaar kan word". Die feit is egter dat nie alle blikke waarin koek gebêre of bewaar word as 'n koekblik benoem sal word nie. Die leksikograaf moet kan aantoon dat met koekblik meestal 'n spesiale soort blik bedoel word en hierdie kwalifikasie word gedoen met die uitdrukkinge "meestal" en "gewoonlik".

Insgelyks word voorbeelde gebruik, gewoonlik voorafgegaan deur die kwalifikasies "soos" en "byvoorbeeld", om definisies wat in hulle toepassingsbereik ' $n$ te breë betekeniskategorie kan skep, (met voorbeelde) af te baken.

Met die bostaande motiveer Snijman dus die lang definisies van die WAT. Soos hy aantoon, word die lengte van die definisies op prinsipieel teoretiese gronde en op legitieme leksikografiese oorwegings gebaseer. Alhoewel die WAT dus ten opsigte van die lengte van die definisies daarvan ' $n$ ooreenkoms met die ensiklopedie vertoon, word die lengte as sodanig nie ingegee deur saakbeskrywing of deur die doel van die ensiklopedie, naamlik om die sistematiek in die kennis van die referente van woorde te beskryf nie.

Snijman verwerp op dieselfde gronde die gebruik van die soort kort "labelling"-definisie van die historiese woordeboek. Volgens Snijman (1995d: 145 ) is die hoofkenmerk van hierdie definisietipe die "prinsipiële ongedifferensieerdheid" daarvan, d.i. slegs "'n sekere vae kern (van die betekenis van 'n woord - PHS) word gegee wat in sy werking onbegrens is". Maar die inherente vaagheid van hierdie definisietipe maak dit onbruikbaar as die strewe is na volledige ontleding en presisie in die betekenisbeskrywing.

'n Ander voorstel wat Snijman verwerp, is dat leksikografiese definisies die vervangingstoets moet kan deurstaan, d.i. dat die definisie (met behoud van betekenis) die woord in die taalgebruikskonteks moet kan vervang (vgl. Snijman 1995d: 144). Die implikasie hiervan is dat enkel en alleen daardie betekeniskenmerke in 'n definisie ingevoer moet word wat hierdie vervanging moontlik maak. Die onhoudbaarheid van hierdie inperking op die vorm en inhoud van die definisie is al uit verskeie oorde gelug. Snijman se eie standpunt is dat as mens op grond van verskeie ander oorweginge (gemotiveerd) 
betekeniskenmerke in die definisie invoer, hierdie vereiste nie afgedwing kan word nie. Meer prinsipieel gestel (vgl. Snijman 1995g: 190):

Maar aangesien die definisie 'n potensialiteit ten opsigte van gebruik aangee, kan daar in 'n gegewe geval minder onderskeidinge geaktueer word as wat in die omskrywing latent gegee word. So sal byvoorbeeld die aspek dat koffie kafeïne bevat nie geaktueer word as ek koffie in 'n gewone kafee bestel nie, maar dit kan wel die geval wees as ek dit bestel in 'n kafee wat kafeïnevrye koffie bedien.

Snijman (1995g: 196) wys egter daarop dat die vervangingsbeginsel nuttig kan wees om presisie met kondensering te verbind, maar dat die vervangingsbeginsel nie op grond van prinsipieel teoretiese oorweginge op die leksikografiese definisie afgedwing kan word nie.

Alhoewel die lengte van die WAT se definisies goed gemotiveer kan word, bly dit ' $n$ feit dat die strewe na die verantwoording van elke gebruikstoepassing en relasie van ' $n$ woord onvermydelik daartoe gelei het dat die artikels besonderlik uitgedy het (vgl. Snijman 1995f: 185). Daarmee is nie net die oorsigtelikheid van die betekenisbeskrywing nadelig beïnvloed nie, maar ook die poging om die WAT so gou as moontlik te voltooi. Hy bied egter self 'n oplossing hiervoor, naamlik om fyner betekenisonderskeidings te onderbring in breër onderskeidings en deur randgebruike wat nie nuwe ontwikkelinge verteenwoordig nie, te negeer, maar dan met inagneming van die formele eenheid van die WAT (vgl. Snijman 1995f: 185). Die belangrike punt is dat dit hier in die prosesse van keuring en verkorting gaan om 'n praktiese eerder as 'n teoretiese eis waaraan die woordeboek sal moet voldoen.

Gegee al die oorwegings wat by die seleksie van kenmerke ' $n$ rol speel, is die omvattende leksikografiese definisie onvermydelik. Snijman (1995f: 182) wys egter wel daarop dat dit dikwels 'n kwessie "van meer of minder" is na gelang van die vermoë van individuele leksikograwe om beknop te formuleer. In ander gevalle word lengte afgedwing omdat sommige woorde "meer stellige onderrichting" vereis as ander. Dit neem egter nie weg dat die leksikograaf in die algemeen moet streef na 'n so beknop moontlike formulering van definisies nie.

'n Ander soort oorweging om definisies te beperk, sou wees om 'n onderskeid te maak tussen die definiëring van sogenaamde "algemene en bekende" woorde en minder bekende ("moeilike") woorde. Snijman (1995d: 145) se uitgangspunt is dat die definiëring van bekende woorde, soos tafel en mens, ter wille van presiese beskrywing dieselfde probleme lewer as die sogenaamde moeilike woorde indien mens ook eersgenoemde presies wil omskryf; gevolglik word sulke woorde oor dieselfde kam geskeer.

Ten slotte moet daar gewys word op Snijman se repliek op die kritici dat die WAT illustrasies en voorbeeldsinne gebruik om inligting oor die referente van woorde in te smokkel. Sy uitgangspunte hieroor hang ten nouste saam met 
die siening wat hy het oor die linguistiese relevansie van sogenaamde "saaklike" kenmerke en die doelstellinge van die leksikografiese definisie.

Die gebruik van illustrasies / visuele materiaal (tabelle, tekeninge, kaarte, foto's van persone, diere, instrumente, ens.) in woordeboeke en ensiklopedieë het 'n lang geskiedenis (vgl. Wolf 1992: 24-29; Snijman 1995g: 197). Die gebruik van illustrasies is egter ' $n$ kenmerk van verskeie tekstipes en nie net van die ensiklopedie nie sodat hulle gebruik in verklarende woordeboeke nie sonder meer as 'n ensiklopediese kenmerk beskou kan word nie.

In historiese woordeboeke word hulle meestal nie gebruik nie, gegee die fokus van hierdie woordeboeke op die weergawe van die betekenisontwikkelinge van woorde, maar daar is verskeie woordeboeke van die verklarende tipe waarin hulle wel voorkom. Die kritiek teen hulle gebruik in verklarende woordeboeke is dat hulle ter wille van saakbeskrywing ingevoer word en nie ter wille van die betekenisbeskrywing nie. Snijman se standpunt is dat deel van ons kennis van ' $n$ referent van ' $n$ woord juis kennis is van hoe die referent daar uitsien. Gevolglik kan 'n woordeboek van illustrasies gebruik maak "en 'n onaanskoulike inhoud komplementeer deur 'n aanskoulike, wat vervolgens gesamentlik as onaanskoulike in die woord funksioneer as sy betekenis" (vgl. Snijman 1995a: 123 en Snijman 1995e).

Soos reeds vermeld, neem taalgebruiksvoorbeelde ' $n$ sentrale rol in die abstrahering van die betekeniswaardes van woorde in. Oor hulle gebruik in die woordeboek meld Snijman (1995f: 185) dat hulle die funksie het

... van stawing, aanvulling, illustrasie en generasie. Dit dien om die verbindingsmoontlikhede van ' $n$ woord en die begrensing van die toepaslikheid te toon, om aan te dui hoe 'n woord gebruik is en dus gebruik kan word, maar soms ook om addisionele inligting te verstrek.

Die kritiek teen die WAT geld veral die laasgenoemde punt, nl. dat voorbeeldsinne gebruik word om inligting oor die referent van ' $n$ woord in te voer. Snijman gaan nie self verder op hierdie kritiek in nie, maar die gebruik van voorbeeldsinne vir hierdie doel moet beoordeel word teen die feit dat definitoriese sinne een van die hoofbronne is vir die leksikograaf om die betekenis van woorde te agterhaal. Die gebruik van sulke voorbeeldsinne het gevolglik die funksie om die aangebode definisie te staaf. Vir sover sulke voorbeeldsinne wel kenmerke van ' $n$ woord se referent aandui, sou die beoordeling daarvan, in ooreenstemming met Snijman se siening oor die linguistiese relevansie van saakkenmerke, moet uitgaan daarvan of sulke betekeniskenmerke wel ter sake is in die res van die definisie.

Uit die voorgaande is dit duidelik dat Snijman wel deeglik daarin slaag om die leksikografiese praktyke van die WAT teen 'n stel aanvaarde teoretiese aannames te motiveer. Dit bly egter 'n ope vraag of die motivering van die praktyk alleen as voldoende gronde kan dien vir die aanvaarding van die werkwyse van die WAT, en of daar slegs metodiese aanpassings in die WAT nodig is. 
Snijman self weeg sy eie teoretiese aannames nie teen alternatiewe op nie, maar motiveer slegs sy keuse van metodes teen die gekose raamwerk. Nog minder weeg hy die gekose metodes en hulle prioriteitstellinge teen ander, ewe aanvaarbare en teoreties gemotiveerde alternatiewe op.

Een so ' $n$ kwessie is sy afwysing van die sogenaamde "vae definisies" van die historiese woordeboek as basis vir die definisiepraktyk vir die WAT. Sulke "vae" definisies is juis ook ' $n$ uitvloeisel van bepaalde opvattings oor die grense en aard van woordbetekenis, en hierdie soort definisietipe kan ook in terme van bepaalde opvattinge oor die funksie van betekenisbeskrywing en -verklaring in omvattende verklarende woordeboeke gemotiveer word.

' $n$ Tweede algemene probleem is dat Snijman nie die gevolge van sy teoretiese raamwerk vir die leksikografiepraktyk altyd uitspel nie. Die prinsipieel onbegrensde aard van ensiklopediese kennis is byvoorbeeld ' $n$ probleem waarmee daar in verskeie leksikaal semantiese teorieë geworstel word. Hierdie probleem word nie teen die agtergrond van hierdie teorieë in meer diepte ontleed en die gevolge daarvan vir die leksikografiepraktyk uitgespel en teen mekaar opgeweeg nie.

Ten slotte moet mens ook daarop wys dat Snijman slegs in enkele gevalle aantoon hoe beginsel en praktyk in die geval van die WAT soms uiteenloop. Dit is dikwels hierdie diskrepansie tussen die gestelde metaleksikografiese uitgangspunte en die praktyk wat in die WAT neerslag vind, wat taalkundiges irriteer.

\subsection{Die opname en beskrywing van eiename}

Gegee die feit dat die grootste groep behandelde lemmas in 'n ensiklopedie (soos byvoorbeeld die Encyclopaedia Britannica) tot die kategorie eiename behoort, erken Snijman (1995f: 179) dat die WAT in hierdie opsig "in 'n ruim mate" as "ensiklopedies" bestempel kan word. Hy voeg egter die belangrike kwalifikasie by dat die WAT nie persoonsname soos Napoleon en plekname soos Afrika insluit nie. Die WAT beperk hom tot die opname van "mitologiese, volks- en sterrekundige name ..., eiename wat ook oordragtelik gebruik word, soos Arkadië, of verskynsels of uitvindings genoem na persone, soos die beweging van Brown of die wet van Gay-Lussac" (Snijman 1995f: 179).

Snijman gaan nie verder in op die hele probleem of ensiklopediese aard van die opname van eiename in verklarende woordeboeke nie, behalwe in die stuk (Snijman 1995i) waarin hy dit het oor die skryfwyse van afleidings en samestellings waarvan ' $n$ komponent 'n eienaam of afleiding daarvan is, byvoorbeeld dieselmotor, bunsenbrander en loganbessie.

Wat vir die ensiklopediese aard van die WAT van belang is, is die onderskeid tussen eiename (en afleidings van en samestellings met eiename) en soortname. Vanuit 'n linguistiese en leksikografiese oogpunt is hierdie onderskeid tussen eiename (wat na 'n bepaalde individu verwys) en soortnaam- 
woorde wat na 'n soort (klas of kategorie) verwys van wesentlike belang omdat daar nog altyd geen wesentlike beswaar teen die opname van soortnaamwoorde in verklarende woordeboeke was nie. Die opname van soortname wat op eiename berus en afleidings en samestellings met ' $n$ eienaamskomponent, is dus wesentlik nie problematies vir sover hulle soortname is en na soort-, klasof kategoriale konsepte verwys nie.

Die beswaar teen die opname van eiename steun op die uitgangspunt dat eiename nie betekenis het nie, maar slegs gebruik word om na ' $n$ referent (persoon, plek) te verwys. Enige poging om dus die "betekenis" van 'n eienaam te beskryf, sou moes neerkom op 'n beskrywing van die spesifieke individu of plek, d.w.s. die referent van die eienaam. Snijman (1995f: 174) meld dan ook dat in die ensiklopedie die behandeling van eiename bepaal word "deur die saaklike gegewens, dikwels veelvuldig individuerende besonderhede wat met sulke name saamhang". Hierteenoor verwys alle ander woorde in 'n taal na 'n soort- of klasbegrip en die beskrywing van die betekenis hiervan sou 'n beskrywing moet wees van die betrokke begrip.

Hier kan net opgemerk word dat die rigiede onderskeid tussen eiename en soortname op verskeie gronde bevraagteken kan word. Benewens die ooreenkoms in hulle verwysende funksie, is dit in baie gevalle besonder moeilik om te bepaal of ' $n$ eienaam (vgl. byvoorbeeld produkname) slegs individuele entiteite denoteer en nie ook kategoriekonsepte nie. Insgelyks kan mens aanvoer dat in die geval van samestellings met eiename as komponente en afleidings van eiename die individuerende kenmerke van die referent van so ' $n$ eienaam wesentlike deel uitmaak van die afleiding of samestelling se klasbetekenis (vgl. byvoorbeeld machiavellisme en machiavellisties). In sulke gevalle is dit nie ' $n$ kwessie dat inligting oor ' $n$ bepaalde individu in die verklarende woordeboek opgeneem word nie. Die vraag is eerder: Watter en hoeveel van hierdie kenmerke is vir die beskrywing van die betekenis van die soortnaam van belang? Al hierdie oorweginge is duidelik ' $n$ teken dat die kwessie van die opname en leksikografiese beskrywing van eiename in verklarende woordeboeke vanuit 'n teoretiese hoek nie te simplisties benader moet word nie.

By die beoordeling van die ensiklopediese aard van die opname van eiename in die verklarende woordeboek moet verder twee aspekte in aanmerking geneem word, $\mathrm{nl}$. die aantal opgenome eiename en die bewerking van hierdie lemmas. Mens hoef geen tellings te gaan uitvoer om te kan konstateer dat verklarende woordeboeke veel minder as die ongeveer $72 \%$ eiename van 'n ensiklopedie soos die Encyclopaedia Britannica opneem nie. Die grootste gros opnames is uit die kategorie soortnaamwoorde, afleidings of samestellings op grond daarvan, werkwoorde en adjektiewe.

Die opname van eiename in verklarende woordeboeke word ook anders as in die ensiklopedie gemotiveer. By laasgenoemde gaan dit om 'n uiteensetting van die geheel van kennis wat met die individu of plek verbind is. In die geval van die verklarende woordeboek word die opname van eiename gemotiveer op grond van die grammatiese leiding wat die verklarende woordeboek 
aan die gebruiker moet gee oor sake soos die spelling, uitspraak en sintaktiese beperkinge, die onderskeid tussen tipiese mans- en vrouename in 'n kultuur, die volle en verkorte vorme van name; en die registerverskille tussen "volle" name en byvoorbeeld byname. Die meeste van hierdie sake word as aspekte van die linguistiese kenmerke van eiename as leksikale items beskou, en daar word aanvaar dat dit deel van die grammaties-toeligtende funksie van die verklarende woordeboek is om aan die gebruiker leiding hieroor te gee (vgl. Wolf 1992: 277). In die lig hiervan word leksikografiese definisies van die tipe "Piet: naam vir 'n manspersoon" gewoonlik in verklarende woordeboeke aanvaar. Wolf (1992: 279) toon egter wel aan dat eiename van hierdie tipe wat volop in ensiklopedieë voorkom, relatief 'n klein deeltjie van die lemmas van ensiklopediese verklarende woordeboeke uitmaak.

'n Tweede motivering vir die opname van eiename is die feit dat die woordeboek die gebruiker wil help met die probleme wat hy sogenaamd met eiename in die dekodering van tekste kan ondervind. Die suksesvolle begryp van 'n teks vereis dikwels 'n elementêre agtergrondskennis van 'n persoon of plek waarna so 'n eienaam verwys. Laasgenoemde het gelei tot die soort kort "definisie" van ' $n$ eienaam waarin ' $n$ individu of plek se bekendheid slegs in een of twee kenmerke vasgevat word. Wat dit betref, is daar dus ook 'n wesentlike verskil tussen die verklarende woordeboek en die ensiklopedie met sy uitvoerige beskrywing van die kennis oor die referente van eiename (vgl. verder die bespreking in Wolf 1992: 274-280 en Mufwene 1984). In 'n geval soos hierdie is die onderskeid tussen die verklarende woordeboek en die ensiklopedie een van die hoeveelheid kenmerke wat in die beskrywing opgeneem word.

In die geval van die vroeër dele van die WAT kom daar ' $n$ derde motivering by, naamlik die gebrek wat daar aanvanklik in Afrikaans aan ensiklopedieë was; gevolglik het die redaksie van die WAT dit as hulle taak gesien om in hierdie behoefte te voorsien. Hierdie situasie het intussen verander, sodat die opname van eiename moeilik in terme van die onbeskikbaarheid van ander inligtingsbronne gemotiveer kan word. Al werklike motivering vir die opname van eiename (gekombineer met die soort kort definisie) is ' $n$ suiwer pragmatiese een, naamlik dat dit vir die gebruiker gerieflik is as die soort inligting wat tradisioneel in die ensiklopedie voorkom, ook in 'n enkele verklarende woordeboek opgeneem is. Daarmee word die bruikbaarheid van die verklarende woordeboek vir die gebruiker verhoog.

Ten slotte moet daar ook verwys word na die praktyk in verklarende woordeboeke (ook in die WAT) om sogenaamde "motiverende" inligting in te voer in die artikels van soortnaamlemmas wat van eiename afgelei is of 'n eienaam as ' $n$ komponent het. ' $n$ Voorbeeld hiervan is die vermelding in die WAT by die lemma bunsenbrander "so genoem na R.W. Bunsen (1811-99), Duitse skeikundige", wat 'n motivering verskaf vir die benoeming van hierdie soort lamp as bunsenbrander. Hier word die soort kort ensiklopediese definisie dus as onderdeel van die leksikografiese beskrywing van 'n soortnaambegrip ingevoer. 
Die vraag sou gestel kon word of sulke inligting hoegenaamd deel van die betekenis van die lemma bunsenbrander is. In Swanepoel (1992) word daar na aanleiding van Lakoff (1987) aangevoer dat sulke inligting die gebruiker help om die betekenis van arbitrêre leksikale items (teenoor komposioneel gemotiveerde leksikale items) makliker te verstaan en te onthou, en om die woord makliker te gebruik. Dit is duidelik 'n kognitief-pedagogiese motivering hierdie wat ten nouste saamhang met die taak van die verklarende woordeboek om die betekenis van die opgenome lemmas vir die gebruiker te verduidelik en om hom / haar in staat te stel om die woord korrek te gebruik. Alhoewel daar dus prinsipieel-teoretiese besware teen die insmokkeling van hierdie soort inligting in die verklarende woordeboek geopper sou kon word, kan die invoering daarvan tog op grond van legitieme doelstellinge van die verklarende woordeboek gemotiveer word. (Vgl. in hierdie verband ook Fillmore (1994) waar die invoering van motiverende inligting teoreties gefundeer word.)

\subsection{Die opname en beskrywing van tegniese en wetenskaplike terme}

Soos Wolf (1992: 273 e.v.) aantoon, is dit ' $n$ kenmerk van die ensiklopediese verklarende woordeboek dat die aantal lemmas oor die jare toegeneem het, hoofsaaklik (i) as gevolg van die feit dat alle naamwoordelike, werkwoordelike en adjektiwiese afleidings van bestaande lemmas as aparte lemmas opgeneem is, en (ii) deur die opname van veel meer vakterminologie. Soms is die aantal lemmas uitgebrei deurdat ook alle moontlike afleidings van vakterme die status van aparte lemmas gekry het.

Verklarende woordeboeke verskil in hierdie opsig egter van 'n ensiklopedie soos die Encyclopaedia Britannica. Wolf (1992: 280-281) wys daarop dat ensiklopedieë nie meer vakterme insluit as die verklarende woordeboek nie, nóg as aparte lemmas, nóg as deel van woordeboekartikels. Daarby het nie alle lemmas in ensiklopediee die status van terme nie - baie van die lemmas is algemene omgangswoorde, maar oor hulle referente is daar heelwat wetenskaplike kennis beskikbaar. Verklarende woordeboeke, veral dié van die ensiklopediese soort, sluit dus in die algemeen meer vakterme as 'n ensiklopedie in. Die vraag is dan inderdaad of die verklarende woordeboek ten opsigte van die opname van vakterminologie nie eerder met die terminologiewoordeboek / vakwoordeboek as die ensiklopedie vergelyk moet word nie.

Die insluiting van vakterme in die verklarende woordeboek volg uit die feit dat die uitbreiding van die woordeskat van die meeste tale juis op die gebied van wetenskaplike terme lê. Dit is dus onvermydelik dat woordeboeke hierdie feit sal moet verdiskonteer.

Wat die opname van tegniese terme betref, het Snijman se voorganger Schoonees reeds in 1958 (vgl. Snijman 1995f: 177) om heel pragmatiese redes op die formaat van die ensiklopediese verklarende woordeboek besluit: 
- omdat dit vir die gebruiker makliker is as die hele term- en woordvoorraad van 'n taal in een woordeboek aangebied word (soos Snijman (1995f: 179) tereg aantoon, het die WAT in hierdie opsig aangesluit by 'n woordeboek soos Webster's);

- omdat daar aan die beginjare in die ontwikkeling van Afrikaans geen vakwoordeboeke of organisasies was wat na die standaardisering van die vakterminologie kon omsien nie; en

- omdat die opname van terminologie 'n breër spektrum taalgebruikers rondom die samestelling (en uiteindelike simboolwaarde) van die WAT sou betrek.

Bostaande het uitgeloop op die algemene doelstelling van die WAT (Deel I, p. iii) om "so volledig moontlik, 'n beeld te gee van die A frikaanse taalskat in sy ruimste omvang".

Dit het egter gou geblyk dat met die kennisontploffing die afgelope twee eeue en die gepaardgaande proliferasie van nuwe terme en met die vestiging van instansies wat terminologiewerk verrig, soos die Nasionale Terminologiediens, hierdie pragmatiese oorwegings onhoudbaar geword het. Voortgesette opname van soveel wetenskaplike terminologie as moontlik hou die wesentlike gevaar in dat die WAT verswelg sou kon word deur wetenskaplike terme en dat dit die voltooiing van die WAT uitermate sou kon vertraag.

Wat die opname van vakterminologie betref, is die WAT in dieselfde posisie as die meeste omvattende verklarende woordeboeke. Die algemene leksikografiese uitgangspunt is vandag dan ook dat 'n linguistiese woordeboek slegs die terminologie behoort op te neem en te verklaar wat tot die algemene omgangstaal deurgedring het.

Daarmee is die probleem rondom die opname van terminologie natuurlik nog nie opgelos nie. Van die vernaamste probleme is: die groot hoeveelhede terme wat in niewetenskaplike diskoerse voorkom; die feit dat baie van hierdie terme 'n kort lewensduur het of dat ander lank voor nuwe bewerkings van 'n woordeboek reeds verouderd is (of verdwyn het); en dat nuwe vakgebiede (ook weer met 'n eie terminologie) voortdurend aan die ontwikkel is - faktore wat die uiteindelike seleksie van terme vir opname in 'n woordeboek nog steeds problematies maak.

Die WAT het volgens Snijman (1995f: 179-181) in hierdie opsig ook 'n koerswysiging gemaak in ooreenstemming met die algemeen aanvaarde leksikografiese uitgangspunt - 'n uitgangspunt wat die redaksie van die WAT ook vanaf Deel IX gevolg het (vgl. p. i):

... hoogs gespesialiseerde vakterme wat slegs deur die vakspesialis benut word, is nie opgeneem nie. Vaktaal is slegs opgeneem indien daar bewyse in die databasis gevind is dat sulke terme ook in die algemene spreek-en skryftaal gebruiklik is. 
Snijman (1995f: 181) het in sy bespreking van die aangeleentheid egter 'n belangrike kwalifikasie bygevoeg, nl. dat ook "min of meer die basiese terme van die verskillende vakgebiede" opgeneem sal word en dat dié "ook in tegniese opsig, deeglik" uitgewerk sal word in samewerking met kenners uit die verskillende vakgebiede.

Alhoewel dit gestel word dat die seleksie van die sogenaamde "grondwoorde" van elke afdeling van die tegnologie en die wetenskap teen hulle gebruiklikheid in die algemene omgangstaal opgeweeg sal word (en nie net op grond van wat tegnici en wetenskaplikes as die basiese terme van hulle vakgebied beskou nie) laat bogenoemde kwalifikasie nog steeds die deur oop vir die opname van meer terme as wat in die omgangstaal voorkom. Daarmee laat die WAT hom dus nie net deur gebruiklikheid in die algemene omgangstaal lei nie, maar ook deur die inligtingsbehoeftes van die potensiële gebruiksgroep daarvan en die algemene bruikbaarheid van die WAT as naslaanwerk.

Dit laat mens wel met die vraag of enige verklarende woordeboek, veral vanweë die terminologiese omvang van elke vakgebied, ook nog kan poog om vir die wetenskaplike en tegniese leek ' $n$ inleiding tot die kennis in daardie vakgebiede (via die opname en verklaring van die basiese terme daarvan) te wees. Indien dit wel die strewe is, dan kry so 'n "opvoedkundige" of inligtingsbeginsel - juis 'n primêre strewe van die ensiklopedie - in die seleksie van terme die voorrang en nie die deskriptiewe beginsel, soos vandag algemeen aanvaar word nie.

Die leksikografiese beskrywing van terme is eweneens 'n problematiese aspek van die verklarende woordeboek waarop Snijman in sy opstelle nie in besonderhede ingaan nie. Hy volstaan met die stelling dat die grondwoorde van elke vakgebied in samewerking met kenners van daardie vakgebiede bewerk sal word.

Twee problematiese aspekte van die ensiklopediese werkwyse in verklarende woordeboeke is hier ter sake, nl. die wetenskaplike definiëring van terme en die wetenskaplike definiëring van omgangswoorde wat nie meer streng genome as vakterme beskou kan word nie. Vir sover leksikografiese definisies steun op die kennis wat vakwetenskaplikes oor die referente van hierdie terme of woorde het, word leksikografiese definisies wat hierdie kennis verdiskonteer, as ensiklopedies van aard beskou (vgl. ook Swanepoel 1989).

Dit word soms as uitgangspunt gestel dat 'n leksikografiese definisie die leek se kennis van 'n term moet weerspieël. So 'n uitgangspunt is egter nie sonder meer onproblematies nie omdat daar baie terme met die status van omgangsvorme is, byvoorbeeld terme vir motoronderdele, waarvan die lekekennis niks anders as die basiese wetenskaplike kennis oor die referent is nie. Die probleem neem toe in gevalle waar 'n term wel tot die omgangstaal deurgedring het maar nog steeds 'n beperkte gebruik het. In sulke gevalle verlaat leksikograwe hulle op die wetenskaplike kennis oor die referente van terme omdat daar in elk geval geen konsensus oor die betekenis van ' $n$ woord onder die lekepubliek gekry sal kan word nie (vgl. Wolf 1992: 286). Daarmee word nie 
aanvaar dat daar nie 'n verskil tussen die leek se interpretasie van 'n term en dié van die vakwetenskaplike kan wees nie, maar wel dat die probleme met die vasstelling van hierdie verskille so groot is dat leksikograwe - as pragmatiese oplossing - hulle op die vakwetenskaplike definisie verlaat. Met hierdie werkwyse ontkom die leksikograaf egter nie aan die gevaar van 'n ander vorm van preskriptiwisme nie omdat vakspesifieke inhoude van 'n opgenome term as die betekenis van 'n lemma voorgehou word.

Dieselfde soort probleem doen hom voor in die geval van die wetenskaplike / ensiklopediese status al dan nie van spesifieke betekeniskomponente in leksikografiese definisies. Uiteraard verwag mens dat daar oorvleueling sal wees tussen die kennis wat wetenskaplikes met woorde (sowel in hulle hoedanigheid as terme en as omgangswoorde) assosieer en die kennis wat die leek daarmee sal verbind. Of mens dan in die een geval met saakkennis en in die ander met legitieme linguistiese komponente van die betekenis van 'n woord te make het, is 'n saak wat reeds hier bo bespreek is.

Dit is dus eintlik net in die geval van baie bekende woorde, soos dié vir diere, sekere plante, prosesse, ens., dat 'n mens uit die definisies sou kon aflei watter kennis wetenskaplik is en watter nie, of watter definisies as wetenskaplik beskou sou kon word en watter nie. In sulke gevalle poog die leksikograaf meestal om deur verskillende definisies eers van die omgangsbetekenis en dan van die meer spesifieke betekenisonderskeidings in bepaalde vakgebiede rekenskap te gee.

Die betekenisbeskrywing van die lemma leemgrond in WAT Deel IX illustreer hierdie werkwyse, maar ook die problematiese daarvan, duidelik. In $H A T^{1}$ se definisie (onder leem) word slegs gemeld dat leemgrond die betekenis "'n kleierige grondsoort" het. Baie duidelik word hier te min inligting verskaf om die onderskeid tussen die betekenis van leemgrond en kleigrond duidelik te maak. In die WAT word daar eerstens 'n omvattender definisie van die omgangsbetekenis van die woord gegee en daarna 'n definisie van 'n vakkundige aard:

Grond met 'n gunstige verhouding tussen sand, slik en klei, wat taamlik baie water kan hou en geskik is vir die verbouing van 'n wye verskeidenheid gewasse; meer bep., (grondkunde) 'n grondtekstuurklas saamgestel uit klei, slik en sand in 'n verhouding wat wissel volgens verskillende klassifikasiestelsels en wat vir S.A. vasgestel is op 7-27\% klei, $28-50 \%$ slik en $24-52 \%$ sand.

Hierna volg daar 'n aantal voorbeeldsinne uit landbou publikasies, d.w.s juis uit gespesialiseerde tydskrifte vir die boer of tuinier, maar nie uit die algemene spreektaal in 'n nielandboukundige konteks nie.

Dit laat mens nog steeds met die vraag of sulke inligting oor die grondsamestelling wel in 'n verklarende woordeboek verskaf moet word. Indien die landboukundige leek inligting van hierdie aard nodig het, is die vraag of hy / 
sy ' $n$ verklarende woordeboek hiervoor sou raadpleeg. Verder is dit 'n ope vraag of terme en hulle betekeniswaardes in populêre, maar gespesialiseerde tydskrifte, wel vir opname en behandeling oorweeg moet word. Indien wel, waar trek mens die streep wat die insluiting van sulke terme en die beskrywing van hulle vakwetenskaplike betekenisinhoude betref? (Vgl. in hierdie verband ook die bespreking in Swanepoel (1989).)

\subsection{Die behandeling op een plek van 'n groep verwante woorde}

Volgens Snijman (1995f: 179) gebruik die WAT nie dikwels die metode om groepe verwante leksikale items op 'n enkele plek te hanteer nie sodat dit nie in aanmerking kom vir kritiek onder hierdie punt nie.

Later verwys hy egter self na die feit (vgl. Snijman 1995f: 181) dat die lengte van artikels geraak word deur die praktyk om verskeie tegniese uitdrukkings onder ' $n$ enkele lemma in dieselfde artikel op te neem. Voorbeelde is die artikels by die lemmas kerk, kolloïdaal en klier.

Die uitgangspunt in sulke gevalle is dat afleidings en samestellings met die betrokke trefwoord in aparte artikels behandel word, maar dat meerwoordige leksikale items van die tipe b.nw. + s.nw. wel onder die betrokke adjektief of naamwoord opgeneem word. 'n Illustrasie hiervan is die meerwoordige leksikale items onder die lemma kerk (waarby byvoorbeeld meerwoorduitdrukkings soos Nederduitse Gereformeerde Kerk, Hervormde Kerk en Presbiteriaanse Kerk opgeneem is).

In hierdie werkwyse volg die WAT tot en met Deel VIII 1 die gebruik in ensiklopedieë na (vgl. die bespreking in afdeling 2). Aangesien die lemma van 'n artikel in ' $n$ ensiklopedie ' $n$ onderwerp of tema aandui, word alle verbandhoudende woorde of terme (of hulle eenwoordige of meerwoordige leksikale items is) onder die betrokke lemma behandel.

Die hoofmotivering daarvoor in verklarende woordeboeke is egter nie om die lemma net in sy semantiese veld te plaas, soos wat met die lys van verbandhoudende lekseme (genusterme, sinonieme, antonieme, ens.) gedoen word nie, maar omdat meerwoordige leksikale items in die meeste woordeboeke nie as lemmas opgeneem word nie - 'n praktyk wat al dikwels gekritiseer is omdat die status van sulke uitdrukkings as leksikale items nie daarmee erken word nie (vgl. Gouws 1989).

Die probleem in hierdie geval is dus nie soseer die metodiese ooreenkoms met die ensiklopedie nie, maar wel die feit dat verklarende woordeboeke nog nie ' $n$ behoorlike sisteem vir die opname en verklaring van meerwoordige leksikale items het nie.

Vanaf WAT Deel IX geld die beswaar wat hier gestel word nie meer nie omdat die "tegniese uitdrukkings", wat nou bekend staan as "gespesialiseerde uitdrukkings", as meerwoordige leksikale items in die uitdrukkingsrubriek van 'n artikel gehanteer word. 
'n Ander soort probleem en leksikografiese motivering kom egter aan bod in die behandeling van die lemma kerk. Hier is naamlik 'n stel eiename (kerkname) opgeneem en die behandeling is tipies ensiklopedies. Die ensiklopediese behandeling word gemotiveer op grond daarvan dat ongelyke behandeling (in omvang) as diskriminasie tussen die besondere kerkgroepe opgevat sou kon word (vgl. Snijman 1995f: 181) - 'n probleem dus wat die leksikograaf vir hom- / haarself skep as hy / sy nie by die werkwyse hou om eiename van 'n kort definisie (met enkele onderskeidende kenmerke) te voorsien nie.

\section{Slotsom}

Die voorgaande illustreer duidelik dat die vraag na die ensiklopediese in verklarende woordeboeke nie net benader kan word uit 'n naïewe kontrasstelling tussen leksikale betekenis en saak nie. Die kompleksiteite van die linguistiesteoretiese kwessies en die vele leksikografies-pragmatiese faktore wat op die spel is, onderstreep die feit dat simplistiese antwoorde op hierdie probleem ook nie moontlik is nie.

Snijman het in sy opstelle in hierdie bundel geslaag om verskeie van die kompleksiteite van hierdie problematiek duidelik na vore te bring. Daarmee het hy ' $n$ uiters waardevolle bydrae tot die diskoers oor die ensiklopediese in verklarende woordeboeke gelewer, in die besonder oor die relasie tussen kennis van leksikale betekenis en kennis van die referent van ' $n$ woord.

Ten slotte moet daarop gewys word dat dit besonder moeilik is om evaluerend met die ensiklopediese kenmerke in verklarende woordeboeke om te gaan. In die hoogs kompeterende woordeboekmark van vandag word verskeie hibridiese woordeboeke uitgegee op grond van navorsing oor spesifieke inligtingsbehoeftes van bepaalde gebruikersgroepe. Die vraagstuk na die legitimiteit van sulke woordeboeke is dan selde 'n kwessie omdat woordeboekprodukte verskaf word op grond van sulke inligtingsbehoeftes. Woordeboeksamestellers kompeteer ook met mekaar om beter produkte op die mark te kry. Veel meer as net metaleksikografiese oorwegings, soos finansiële oorwegings en die tydige voltooiing van 'n woordeboek, speel dan 'n primêre rol, nie prinsipieelteoretiese kwessies nie.

\section{Verwysings}

Combrink, Johan. 1979. Die sesde deel van die W.A.T. Standpunte 32(2): 49-64.

Eksteen, L.C. 1968. Ensiklopediese beskrywing in die verklarende leksikografie. Tydskrif vir Geestesuetenskappe 8: 236-249.

Fillmore, Charles J. 1994. Lexicography and Ethnographic Semantics. Ongepubliseerde referaat, EURALEX-kongres, Amsterdam, 1994.

Geeraerts, D. 1993. Vagueness's puzzles, polysemy's vagaries. Cognitive Linguistics 4-3: 223-272. 
Gouws, R.H. 1989. Setsels as makrostruktuurelemente van Afrikaanse woordeboeke. Suid-Afrikaanse Tydskrif vir Taalkunde 7(2): 59-67.

Lakoff, George. 1987. Women, Fire and Dangerous Things. Chicago: University of Chicago Press.

Mufwene, Salikoko S. 1984. The Manifold Obligations of the Dictionary to Its Users. Dictionaries 6: 1-30.

Snijman, F.J. 1995. Die leksikograaf as eksegeet. Opstelle en lesings. Stellenbosch: Buro van die WAT.

Snijman, F.J. 1995a. Aspekte van die leksikografie. Snijman, F.J.: 117-126.

Snijman, F.J. 1995b. Woordidentiteit. Snijman, F.J.: 127-134.

Snijman, F.J. 1995c. Struktuur van die woordbetekenis. Snijman, F.J.: 135-142.

Snijman, F.J. 1995d. Die definisieprobleem in die leksikografie. Snijman, F.J.: 143-156.

Snijman, F.J. 1995e. Is illustrasies in 'n woordeboek funksioneel? Snijman, F.J.: 157-168.

Snijman, F.J. 1995f. Oor die ensiklopediese. Snijman, F.J.: 169-186.

Snijman, F.J. 1995g. Ponering sonder voldoende fundering. Snijman, F.J.: 189-200.

Snijman, F.J. 1995h. Bespreking van WAT VI deur J. Combrink - 'n paar opmerkings. Snijman, F.J.: 201-211.

Snijman, F.J. 1995i. Moeilikheid met die hoofletter. Snijman, F.J.: 107-114.

Swanepoel, P.H. 1989. Botsing tussen leksikografiese beginsel en leksikografiese praktyk; enkele gedagtes oor die terminologiebeleid van die WAT. Suid-Afrikaanse Tydskrif vir Taalkunde 7(2): 6-19.

Swanepoel, P.H. 1992. Linguistic Motivation and Its Lexicographical Application. South African Jounal of Linguistics 10(2): 49-60.

Taylor, J. 1992. How Many Meanings Does a Word Have? Spil 25: 133-168.

Van Heerden, C. 1977. Insigte in semantiek nog nie in die kol. Die Volksblad, 21 September 1977: 17.

Wolf, M. Carlan. 1992. The Rise of Encyclopedicity in Monolingual English Dictioneries of the Nineteenth Century. Doktorale proefskrif. Westfälischen Wilhelms-Universität, Münster.

Woordeboek van die Afrikaanse Taal. Deel I. 1950. Pretoria: Staatsdrukker.

Woordeboek van die Afrikan nse Taal. Deel VIII. 1991. Stellenbosch: Buro van die WAT.

Woordeboek zan die Afrikaanse Taal. Deel IX. 1994. Stellenbosch: Buro van die WAT.

Zgusta, L. 1971. Manual of Lexicography. The Hague / Paris: Mouton. 